\title{
Resilience in Post-Khmer Rouge Cambodia: Systemic Dimensions and the Limited Contributions of Transitional Justice
}

\author{
Timothy Williams ${ }^{1}$
}

\section{INTRODUCTION}

Since the 7os, I have thought that Cambodia had no more peace [...] There are only the strong people, the weaker ones will be dead. That's it. [...]. It is only the leaders who live happily while the normal people don't. They decide on when and who will be alive, who will be dead and who will become the leader. [...] It's quite similar [to the Khmer Rouge period ....]. But this society is different since there are computers, spacecraft and Facebook. That's what is different. [... But it is] the same worry, just a different regime. It's still difficult but just different difficulties.

These words were spoken by an elderly Cambodian man who leads a life of poverty in the rural province of Kampong Cham. ${ }^{2}$ The man is a victim of the totalitarian and genocidal Khmer Rouge regime that turned the country upside down in the 1970s. His life has continued to be extremely hard since the end of the regime; and indeed much evidence suggests that life since the liberation in 1979 has remained difficult for many victims, characterised by poverty, limited (although growing) economic and social opportunities, corruption and nepotism and the hegemony of an authoritarian ruler.

1 The research underlying this chapter was funded by two research grants: 'Victimhood after Mass Violence' (funded by the German Federal Ministry of Economic Cooperation and Development) and 'The Cultural Heritage of Conflict' (funded by the Swedish Research Council under grant number 2016-01460). I would like to thank Roland Kossler for his assistance, as well as Julie Bernath, Roddy Brett, Kirsty Campbell, KEO Duong, Jonathan Leader Maynard, Jan Reinermann, David Simon, SIRIK Savina and Manuel Vogt for their valuable feedback on a draft version of this chapter.

2 Some interviews referred to in this chapter were conducted in 2018 by Julie Bernath in the context of a joint project 'Victimhood after Mass Violence'. These interviews are labelled (JB). All other interviews were conducted by the author. 
Nevertheless, in the aftermath of Democratic Kampuchea and the civil wars that preceded and succeeded it, victims have rebuilt their lives, demonstrating a desire and capacity to survive in the face of extreme hardship. This chapter assesses resilience in post-Khmer Rouge Cambodia through this edited volume's social-ecological lens (Ungar, 2018) to explore how various systems interact to provide resources that enable and foster resilience among victim populations. It demonstrates that while some resources are generated in this resilience process, the political system actually limits them and undermines resilience in exerting political and economic dominance. Fundamentally, systems related to political empowerment, economic opportunity, social structure, rule of law and others interact with each other to promote or undermine the provision of resources.

The chapter also analyses how transitional justice work in Cambodia has affected resilience. It focuses particularly on the Extraordinary Chambers in the Courts of Cambodia (ECCC) - the hybrid Cambodian-United Nations (UN) tribunal that was created to deliver justice for the Khmer Rouge period and its programme of victim participation and moral and collective reparations. I argue that while the ECCC has the potential to contribute to resilience (and does for some victims), its design and procedures constrain it in this regard, even inadvertently reinforcing broader marginalising systemic dynamics. This does not paint a bright picture of the relationship between transitional justice and adaptive peacebuilding (see de Coning, 2018). The key point, however, is that national actors in Cambodia recognise that they can gain significant advantages through corrupt practices and autocratic power (Un, 2019), and thus they have used transitional justice strategically to undermine peacebuilding (Gidley, 2019; Killean, 2018; Manning, 2017).

Pursuing a multi-systemic approach means that this chapter's engagement with social-ecological resilience is complex and at times messy. Nevertheless, I endeavour to portray the interlinkages between the systems as clearly as possible, using empirical data. First, I utilise data from a nation-wide survey conducted in 2018 with 439 victims of the Khmer Rouge, most of whom had participated in transitional justice processes in some form, as well as follow-up interviews with sixty-seven of them (for more details, see Williams et al., 2018). Second, I draw on interviews conducted with international and Cambodian transitional justice and memory actors from the same project and a further project on the politics of memory. Third, my own insights on national political dynamics from regular fieldwork engagement since 2014 complement the above data.

This chapter begins with a brief historical introduction to the Khmer Rouge past. It moves on to discuss resilience and the utility of this volume's multisystemic approach. It proceeds to analyse how different systems have 
contributed to or undermined resilience, with a particular focus on the ECCC, its victim participation programme and its moral and collective reparations. The chapter ends with a discussion of what the case study of Cambodia means for our understanding of adaptive peacebuilding.

\section{THE KHMER ROUGE AND THE LONG SHADOW OF THE PAST}

In 1953, King Norodom Sihanouk secured Cambodia's independence from France and separation from the rest of colonial Indochina (Kiernan, 1985). Sihanouk remained Cambodia's strongman and positioned Cambodia neutrally in the neighbouring Vietnam War (Chandler, 2008a: 233-254; Kiernan, 1996: 17). In opposition to this policy, Prime Minister General Lon Nol led a coup against Sihanouk and realigned foreign policy in a pro-United States (US) direction, allowing bombardment of Viet Cong troops inside Cambodian territory.

In a pragmatic liaison, King Sihanouk drew on his unwavering popularity among the rural population to call upon his subjects to 'come to the jungle' and join a hitherto small and relatively unknown group, later to be known as the Khmer Rouge (Chandler, 1999: 88). The subsequent five-year civil war and US bombardments killed 500,000 people (Chandler, 2008a: 256) and internally displaced large parts of the rural population who fled from the countryside to the cities.

The Khmer Rouge took Phnom Penh on 17 April 1975, winning the civil war, and were welcomed enthusiastically by a war-weary population. However, the Khmer Rouge immediately evacuated the cities (Chandler, 2008a: 256; Kiernan, 1996: 8) and began to implement their vision of a peasant revolution, according to a radical Maoist model. They pledged to take the country back to the 'Year Zero' and rebuild it independently of the imperialist and capitalist West through intense rice production and large-scale irrigation construction (Chandler, 2000: 14; Chandler, 2008a: 264). A quota of three tonnes of rice to be harvested per hectare of land was instituted, a substantial overestimation of realistic productivity levels for most of the country's land. Local leaders were torn between three priorities: first, delivering the quota; second, saving seed for planting next season; and, third, feeding the population. In the end, many local leaders followed strategies that maximised their own security and de-prioritised feeding the population, causing mass starvation (Hinton, 2005: 11; on famine, see DeFalco, 2014).

After taking power, the Khmer Rouge sought to eradicate anyone associated with the former Lon Nol regime (Chandler, 2000: 45); and, as the revolution failed to meet its targets, the leadership around Pol Pot identified 'microbes' 
within the regime intent on undermining the revolution (Chandler, 2000: 4576). The regime became ever more fixated on rooting out these internal enemies, interning, interrogating and executing anyone suspected of trying to jeopardise the revolution, with even minor dissent or rule-breaking classed as anti-revolutionary. Furthermore, the Khmer Rouge understood itself in strongly nationalistic terms, targeting ethnic minorities for annihilation, too. Ultimately, between 1.7 and 2.2 million people died during Democratic Kampuchea, about half from violent deaths and the other half from exhaustion, overwork, sickness or starvation (Tabeau and Kheam, 2009: 19).

Democratic Kampuchea finally ended on 7 January 1979 when defected Khmer Rouge units, supported by Vietnamese troops, invaded and liberated the country. The Khmer Rouge retreated to the Northern and Western borders with Thailand, along with hundreds of thousands of refugees, throwing the country into another civil war wherein multiple factions developed in resistance to the new rulers and Vietnamese occupation of the country (Chandler, 2008a: 277-295). Cambodia remained internationally isolated throughout the 198 os due to international hostility towards Vietnam in the aftermath of US defeat in the Vietnam War (Chandler, 2008a: 277-295), until the Paris Peace Agreement of 1991 and the UN peacekeeping intervention, UNTAC (UN Transitional Authority in Cambodia). With the defection of increasing numbers of Khmer Rouge (and other factions) through the promise of amnesty as part of the government's 'win-win policy', the civil war drew to a close in the late 199os. Subsequently, there was an economic opening to a liberal market economy and democratic reforms. In this new environment, Prime Minister Hun Sen - who had been part of the liberating forces and rose to power in 1984 - was able to quash political threats. He remains in power to this day, reaping significant economic benefits through corruption, land-grabbing and favourable concessions (Global Witness, 2016).

Although the government propagated hatred against the Khmer Rouge during the civil war, once hostilities ended Hun Sen urged people to 'dig a hole and bury the past' (cited in Chandler, 2008b: 356). However, this envisaged 'induced amnesia' (Chandler, 2008b) was ultimately less important to the government than the potential international political capital to be gained from supporting transitional justice. Established in 2003, the ECCC applies international law within the context of the Cambodian judicial system and fills all positions with both international and Cambodian counterparts (for an introduction to the ECCC, see Gidley, 2019; Hughes, 2015; Killean, 2018; Manning, 2017). The judicial mandate of the ECCC is to try the senior leaders and those most responsible for the crimes committed during Democratic 
Kampuchea. As such, and compared with other tribunals, the ECCC has tried relatively few individuals, with verdicts handed down for only three individuals. Further cases are unlikely to go forward due to government pressure to limit the ECCC's activities to the cases already tried. Beyond the ECCC, the broader transitional justice process in Cambodia encompasses considerable non-governmental organisation (NGO) activity, although most of this work is thematically tied to the ECCC (see Hinton, 2018: 43). Many NGOs feed into the tribunal directly, supporting its internationally innovative yet poorly financed victim participation programme (Ryan and McGrew, 2016: 92; Sperfeldt, 2012a).

\section{A MULTI-SYSTEMIC APPROACH TO RESILIENCE AND MULTI-SYSTEMIC CHALLENGES IN CAMBODIA}

This volume approaches resilience as 'processes whereby individuals interact with their environments in ways that facilitate positive psychological, physical and social development' (Ungar, Chapter 1). More than just an individual trait, resilience thus incorporates important social-ecological dimensions, drawing attention to the broader social environment in which the individual is embedded and which, through the resources and opportunities that it offers or fails to provide, fosters or undermines the individual's development. This social environment is diverse, formed of various systems that affect the individual and interact with each other. Hence, resilience is about the interactions between the individual and the social environment, with responsibility for an individual's development partly explained by the quality of a system's functioning (see Ungar, 2018).

In this chapter, I foreground several inter-linked systems. The political system can provide resources to equip individuals with political agency and the ability to shape the contextual structure of their lives. This is closely connected to the legal system, which can provide resources in terms of individual rights and the rule of law, supporting resilience through legal security. The economic system mediates resources through access to economic opportunities that lay the foundation for individual development and the provision of the means to earn a living and secure shelter, as well as more advanced economic goals. Each of these systems can provide resources to individuals, allowing for resilience, but they can also remove these resources or even undermine resilience. Within the scope of this chapter, I demonstrate some of the key interactions between these systems and their repercussions for resilience, before specifically exploring their impact within the context of the ECCC's work. 


\section{Political system}

Political developments over the past four decades since the end of Democratic Kampuchea have had a significant impact on social-ecological resilience in Cambodia. Key to understanding this is the political system itself. Since the 1980s, Cambodia's political system has been dominated by Prime Minister Hun Sen and his Cambodian People's Party (CPP; known until 1991 as the Kampuchean People's Revolutionary Party), with gradual liberalisation beginning with the UNTAC mission and supported by broad peacebuilding efforts in subsequent years. However, while formal democratic institutions are in place, the system is fundamentally illiberal; and, in recent years, there has been a concerted political effort by the government to close the political space, reduce political freedoms and limit the political opposition (Un, 2019). There is direct targeting of opposition politicians, human rights activists and civil society organisations, but the fear of personal repercussions for political dissent also affects the broader population. For example, a female interviewee from Kratie province revealed: 'nowadays people are only scared of the people who hold power. Their relevant institutions. [...] The people dare not to say [anything negative, but] just agree with everything [...] in order to avoid being accused like this or like that'. ${ }^{3}$ While 46 per cent of respondents in a 2018 nation-wide survey felt that they were able to participate to improve things in their community, ${ }^{4}$ the previous quote demonstrates that clear limitations exist for people to exercise their agency.

Moreover, political repression goes beyond just the targeting of politically unfavourable individuals and structural limitations placed on political freedoms and relevant political resources. In 2017, for example, the country's main opposition party, the Cambodian National Rescue Party (CNRP), was dissolved in the run-up to local elections, after significant gains by the opposition in the 2013 national elections (Un, 2019). Furthermore, there has been a crackdown on the free press, with several newspapers being forced to close due to supposedly unpaid tax bills, as well as stricter laws on international funding (Un, 2019), severely limiting the population's access to politically unbiased reporting in print and radio - and thereby weakening resources for the development of political agency. This illiberal backlash also includes a curtailing of NGO activities through the Law on Associations and Non-Governmental Organizations (LANGO), which allows tighter controls on NGOs and has led to several organisations being shut down. Given that many fundamental services are provided by NGOs, this encroachment on the civil society sector not only

3 The interview was conducted in Kratie province in 2018 (JB).

4 Unpublished statistics, used by Williams et al. (2018). 
restricts access to support for human rights violations but also affects many other systems, including community services, business and agriculture, education and physical and mental health. As such, the transformative potential for other systems through NGO work is curtailed. Furthermore, political participation and agency are a key resilience resource (Comes et al., 2019), and hence increasing political disempowerment significantly limits the development of resilience for a large part of the population. Nonetheless, some activists are still able to use alternative spaces, such as social media or radio programmes, to circumvent government control and develop agency, even though these spaces continue to shrink (see Human Rights Watch, 2019).

A further facet of the political system that engages other systems is the issue of corruption. Transparency International rates Cambodia as one of the most corrupt countries worldwide (with 162 out of 180 countries exhibiting less corruption in 2019) (Transparency International, 2019). Corruption is plainly manifest in the extraordinary wealth of government officials, in particular Prime Minister Hun Sen's family; it is estimated to be worth between half and one billion US dollars, owning a network of lucrative companies and holdings. Additionally, Hun Sen's family members occupy various key positions in the administration, military and police (Global Witness, 2016). Corruption also exists in every aspect of public life, with payment of bribes routinely expected for bureaucratic action, police assistance or even access to healthcare. Access to land, contracts and permits is also structured through corruption and nepotism (Hennings, 2016: 226).

\section{Legal system}

Corruption also interacts with the legal system, significantly undermining access to justice and rule of law. For example, a female interviewee from Kampong Cham province explained that one of her nieces, a seven-year-old girl, was raped. The accused 'was detained, but later was bailed out after his mother bribed the authorities'. 5 In more general terms, a villager from Takeo province explained his perspective on courts in the Cambodian justice system: "The court sees only the one side that is powerful and rich, so there is no justice to change the society. If a person is poor [...] and he/she is innocent, the rich person wins the case; thus, our society does not change and it becomes more corrupt'. ${ }^{6}$

5 The interview, with a civil party of case oor at the ECCC, was conducted in Kampong Cham province in 2018 (JB).

6 The interview, with a civil party representative at the ECCC, was conducted in Kampong Cham province in 2018 (JB). 
These injustices permeate various issues and interact with the political system when human rights violations are not prosecuted, or when land-grabbing in the economic system is judicially legitimated. This intersection of systems and their cumulative effects limit resilience and access to potential resources that could, in theory, support resilience.

While corruption is structurally inefficient from a social-ecological perspective on resilience, one way that people deal with it is through participation in patronage networks, in which patrons provide access to resources and security to their clients who, in turn, support the patrons with loyalty and service (Springer, 2011; Un, 2019). This often means that patrons will secure positions for their clients, and a significant part of the money made through corruption and bribes is then passed upwards. These patron-client networks are expansive and extend over many levels, including the state bureaucracy and party structures throughout the country, as well as many other societal and economic relations. This provides an alternative option for individuals to develop resilience and gain access to key resources. For example, the Union of Youth Federations of Cambodia is an influential actor headed by Hun Sen's son, Hun Many, and offers a variety of opportunities to individuals associated with it. However, these patron networks systematically marginalise those who are not well positioned to take advantage of them. Patronage networks also play a role in transitional justice, as discussed in the next section.

\section{Economic system}

Corruption and government control strongly affect the economic system, which is characterised by an absence of any engaged provision of services, particularly in the provinces. Compared with the mass starvation, dire poverty and lack of individual ownership (due to collectivisation) under the Khmer Rouge, and the difficulties of the civil war period, today's residents of Cambodia enjoy a higher degree of economic development and wealth. Nonetheless, the country remains poor; and in a 2018 nation-wide survey of victims of the Khmer Rouge, just over half of respondents 'stated that they did not earn enough to make a living' (Williams et al., 2018: 28). Highlighting this marginal progress, a male interviewee from Kampong Cham province lamented: 'In the past, it was very difficult for us but today it's difficult in the way that we have something to eat, but we don't have a house to live in'. ${ }^{7}$ While part of this poverty can be traced back to the long-term effects of the

7 The interview, with a rejected civil party at the ECCC, was conducted in Kampong Cham province in 2018. 
Khmer Rouge regime's economic policies, the mass killing of intellectuals and the subsequent civil wars, it is also a product of the corrupt and extractive government policies, described above, which lead to a highly unequal distribution of wealth.

Cambodia's economy is industrialising, but it remains dominated by the agricultural sector and three-quarters of the population is rural (World Bank, 2020). This makes insecurities surrounding land rights and increasing cases of land-grabbing highly pertinent issues to resilience in the context of a survival economy that depends on access to land. While increasing industrialisation is providing jobs, foreign investment is predominantly Chinese, de-emphasising human and labour rights and exporting profits in an increasingly extractive way (with the exception of the substantial pay-offs that the government presumably benefits from). This extractive economic tendency, as well as the increased presence of Chinese investors in Cambodia - 43 per cent of foreign direct investments are Chinese (National Bank of Cambodia, 2020) has led to an upsurge of anti-Chinese sentiment throughout the country (Po and Heng, 2019), an interaction between the economic system and social system that reduces social cohesion.

An alternative strategy to enhance resilience in the economic system can be found in migrant labour. The high proportion of young people in the country facilitates this; 65.3 per cent of the population is under 30 (United Nations Development Programme, 2020). Migrant labour occurs both within the country, to urban factories, as well as abroad, through agricultural positions and menial labour, particularly in Thailand (see Parsons et al., 2014). While this migration - which the COVID-19 pandemic has significantly affected (Olsen and Vorn, 2020) - enables resilience through access to economic resources, it has inter-systemic fallout through its effects on the social system of families. In particular, it can contribute to weakening family ties and decentralising them, often leaving young children with elderly relatives while the still young parents migrate for most of the year.

Other relevant systems that go beyond the scope of this chapter could include physical security or spiritual practices in Buddhist traditions (Bennett, 2018; Ledgerwood, 2012). What this section has specifically sought to demonstrate, however, are the complex ways in which three particular systems interact with each other to restrict political agency and access to resilience-supporting resources. The key point is that the lack of resilience is not due to structural deficits, chance or exogenous shocks, such as natural disasters. Rather, it is built into the system to advance personal and political interests. While some access to resources can be traced within each system, for 
the most part powerful actors use their positions to structurally limit access across systems for their own personal benefit.

\section{TRANSITIONAL JUSTICE AND ITS OVERALL LIMITED CONTRIBUTIONS TO RESILIENCE}

Within the political and legal context of Cambodia, there have been various efforts over the years to come to terms with the violent Khmer Rouge past, including the largest transitional justice intervention, the ECCC. While hopes for transitional justice processes are often very high, they also necessarily unfold within the constraints and opportunities of the broader context in which they are structurally embedded. While resilience was not a stated part of the ECCC's mandate, this section highlights the contributions that transitional justice can and has made to resilience in Cambodia while also underlining its significant limitations in this regard. Victims of the Khmer Rouge nevertheless appear to positively assess the impact of transitional justice, despite these limitations. For example, two-thirds of victims in a 2018 nationwide survey opined that the ECCC had brought justice for the victims of the Khmer Rouge regime and their families, while about a quarter believed that the ECCC had delivered justice in conjunction with other factors (Williams et al., 2018: 42).

\section{The Effect of the ECCC's Mandate on Attributing Responsibility}

Undoubtedly, the ECCC's cases to date have contributed to providing justice for the crimes of the Khmer Rouge, even though only three people have been sentenced. This narrow focus on individual criminal responsibility avoids the generalisation of guilt to entire groups - a key aim of international criminal justice more generally - which potentially affects the resilience of social systems in the sense of improving relations in local communities. The focus on a few key individuals arguably also gives judicial credence to a narrow attribution of responsibility that has been politically pursued since the mid1990s alongside the integration of former Khmer Rouge, as does the inclusion of former Khmer Rouge as civil parties at the tribunal (Bernath, 2016). Relatedly, the narrow approach to responsibility for violence has allowed almost all low- and mid-level cadres to claim victimhood under the Khmer Rouge (Williams, 2018a, 2019). This was exemplified by a male interviewee from Kampong Cham province who said: 'I cannot hate them since they just followed the orders; even the commune chief in Pol Pot regime also got killed. 
The officers got killed more than normal people. How can we hate them since they also received the order as well'.

This broad classification of victimhood can lead to tensions in certain communities where former Khmer Rouge who committed atrocities continue to live. However, for the most part, cadres were assigned to work in other areas (Williams, 2018b), allowing the frame of broad victimhood and narrow culpability to appear plausible, thereby aiding the ECCC's contribution to consolidating community relations (Williams, 2018a) - and strengthening resilience resources within social systems.

\section{The Politicisation of the ECCC}

The ECCC's creation came at the end of protracted negotiations and political interference in its work has always existed (Manning, 2017; Orentlicher, 2020; Ryan and McGrew, 2016: 72; Un, 2019; Williams et al., 2018: 45). The government, for example, appoints national staff from within its patronage networks, and these staff have blocked international attempts to progress prosecutions in Cases 003 and 004 , even though more than 80 per cent of victims support these prosecutions (Williams et al., 2018: 62). ${ }^{9}$

The politicised nature of the tribunal has also stymied hopes that it would positively benefit the rule of law and jurisprudence in Cambodia, and contribute to the consolidation of resources within the legal system (Gidley, 2019). Slightly tangential to this, the work of the tribunal has inadvertently masked ongoing human rights violations; it focuses on past 'injustice', even though two-thirds of victims believe that today's problems are more important (Williams et al., 2018: 31). Moreover, by virtue of its embeddedness within the Cambodian legal system, the ECCC provides a degree of legitimacy and normalcy to government intervention in, and control of, the legal system. As such, for the most part, the ECCC has largely failed to positively influence the legal system vis-à-vis the right to legal representation, despite some limited contributions (Soy and Hing, 2019). It has not enabled easier access to justice for victims of today's human rights violations in a national court system that remains rampantly corrupt, and it has accorded greater legitimacy to this national system and to the political interference that occurs within it (DeFalco, 2018).

8 The interview, with a rejected civil party at the ECCC, was conducted in Kampong Cham province in 2018.

9 Notwithstanding political influence, it appears that basic fair trial procedures have not been undermined (Orentlicher, 2020). 
Trials at the ECCC focus, unsurprisingly, on the violence of the Khmer Rouge regime, while giving little space to the broader structures of repression and economic exploitation that are important to some victims in their memory of the past (Williams et al., 2018: 41). The focus of the tribunal's mandate aids the government in its efforts to highlight how it ended Khmer Rouge violence, while deflecting attention from any form of illiberal continuity. In this way, the ECCC is both shaped by and advantageous to the political system. Similarly, the absence within the tribunal's mandate of issues pertaining to economic exploitation precludes debates about ongoing economic marginalisation today, thereby normalising and hiding the lack of resilience resources available. However, the addition of particular topics to the ECCC's work has also provided resilience resources. For example, through the efforts of international civil party lawyer, Silke Studzinsky, forced marriage was recognised as a crime to be addressed by the ECCC. This, in turn, had important repercussions for the social system, where victims were able to understand what happened to them specifically as a crime (Strasser et al., 2015).

\section{Victim Participation}

When it was created, one of the ECCC's most innovative features was that it included a strong degree of victim participation. Victims were able to participate in proceedings not only in the form of witness testimony but also as civil parties and complainants. While the latter only filed a complaint to the ECCC and received recognition of this, civil parties were actual parties to the proceedings, represented by international and national lawyers and afforded various rights - albeit gradually diminished over time - in cooperation with the prosecution (Killean, 2018). They also had the right to apply for moral and collective reparations (discussed below). This provided an opportunity to embed a 'victim-centred' approach (Robins, 2011) at the core of the transitional justice project.

In total, 94 people applied to be civil parties in Case oor (of whom 76 were accepted) and 4,128 in Case ooz (of whom 3,865 were accepted). A further 645 and 2,008 have applied to participate in Cases 003 and 004 , respectively, notwithstanding uncertainties about whether these trials will proceed. ${ }^{10}$ In the context of this chapter, it is also significant that various NGOs offered services and programmes for victims who were officially participating, providing resources for resilience across a range of projects - including psychological

10 All statistics were provided by the ECCC's Victim Support Section in private correspondence (see also Williams et al., 2018: 14). 
counselling, interpersonal dialogues or spaces to share their stories. This strong degree of victim participation could be an important opportunity for transitional justice processes to positively contribute to resilience.

A 2018 nation-wide survey of victims showed that considerable mental health benefits accrued from participating in transitional justice (Williams et al., 2018: 101), which is important in a population that still suffers from the long-term effects of the violent past. ${ }^{11}$ For example, " $69.3 \%$ of civil party respondents agreed that their participation helps them cope with the Khmer Rouge past (compared with $38.5 \%$ of complainants) [ $\ldots$ and] $74.7 \%$ of civil party respondents agreed that being a civil party helps them to feel mentally stronger (complainants: 40.9\%)' (Williams et al., 2018: 101). One civil party representative from Kandal province talked about meeting other civil parties in the context of the tribunal: 'I was very happy not because of money but I got to meet others, so that I could feel relieved and reduce my stress. ${ }^{12}$ Many victims emphasise the therapeutic value of being able not just to meet and talk to others, but also to share stories with them (Williams et al., 2018: 102). A male interviewee from Kampot province who participated in a reparations project reported: 'after I got to talk, I felt very released, especially my anger, as I got to share it with other people, so it made me feel better.' ${ }^{13}$

Besides being able to tell their story and find a voice, material interests are relevant for victim participation, aiding resilience. While economic reparations are not accessible through the ECCC (see the next subsection), civil parties are provided with per diems when participating in programmes or visiting the court. Most interviewees emphasised that these were important and that they would eat as little as possible or share guesthouse rooms in order to save money to take home to their families (Williams et al., 2018: 79). This practice speaks as much to their poverty as it does to the meagre but subjectively important resources it provides in bolstering their economic security and allowing a degree of resilience.

However, three key dynamics structurally limit the potentially positive impact of victim participation. First, victims are only included in the implementation phase of transitional justice and not in its design, meaning that their participation is not on their own terms and thus falls short of a more

${ }^{11}$ While reports of post-traumatic stress disorder (PTSD) are low (Sonis et al., 2009: 532), localised concepts, such as baksbat (literally: broken courage), can be more helpful in understanding psychological suffering in Cambodia (Chhim, 2013).

12 The interview, with a civil party representative at the ECCC, was conducted in Kandal province in 2018 (JB).

13 The interview, with a man who participated in an ECCC reparations project, was conducted in Kampot province in 2018 (JB). 
substantive empowerment (Williams et al., 2018: 54). This is most obvious visà-vis reparations (Sperfeldt, 2012b: 475; Williams et al., 2018: 117), discussed later. Second, participation in events and programmes, as well as visits to court, is theoretically open to all civil parties. However, in practice, these activities are organised by the supporting NGOs, and invitations often run through local focal points (civil party representatives). It is regularly reported that people closest to these key individuals are more likely to be invited; others cannot afford to participate as they need to engage in agricultural or caregiving work. Thus, access to participation opportunities in transitional justice appears to be mediated by power structures and patronage networks, as well as economic position, thereby reinforcing patterns of societal marginalisation visible in the political, legal and economic systems.

Third, not all victims were even able to register and be accepted as civil parties at the ECCC. Of those victimised by the Khmer Rouge, the vast majority are not registered as civil parties. This non-participation is unproblematic when it is voluntary; for example, due to individuals being uninterested or not seeing the benefits of participation. However, non-participation is mostly involuntary; some people did not know that they could apply or how to go about this, and others felt afraid or did not have sufficient resources (time and money) (Williams et al., 2018: 92-93). Most people were registered by NGOs, meaning that those individuals who were not already part of projects had a much slimmer chance of understanding how to register, with potential implications for mental health and other support. Furthermore, even if they did register, 276 out of 4,222 civil party applicants were rejected in the first two cases at the ECCC. Rejection of civil party status is psychologically very difficult for victims, leading to great disappointment, feelings of hopelessness and guilt, and even fears that others will now see them as lesser victims. This underscores that a technical, legal decision has very real consequences for the affected parties (Williams et al., 2018: 86-87).

The differentiation between types of participation (e.g., civil party or complainant) and the varying degree of opportunity to participate due to patronage systems and access create hierarchies of access to justice for victims (Williams et al., 2018: 83). As such, the key resources for resilience that transitional justice processes can provide - in particular the aforementioned mental health benefits, social exchanges with others and limited access to economic benefits - are accessible only to those who can actually participate in them. Not only are there just a few thousand civil parties at the ECCC, but even within the victim participation system access varies significantly (Williams et al., 2018: 69, 107). 


\section{Collective and Moral Reparations}

One aspect of the ECCC's victim participation programme includes access for civil parties to 'collective and moral' reparations. ${ }^{14}$ Even though monetary reparations are explicitly excluded from the ECCC's mandate, they were by far the most requested type of reparations in a 2018 nation-wide survey among victims (Williams et al., 2018: 110). In this sense, victim participation in internationalised criminal tribunals provides a stage for the putting of collective claims in otherwise politically impoverished post-conflict contexts' (Hughes, 2016: 144), thus highlighting how the (lack of) resources in the political system influences how transitional justice is approached. The economic system is also implicated, as poorer respondents were statistically more likely to demand individual financial reparations (Williams et al., 2018: 111). This reflects to some degree the disconnect between, on one hand, the central importance of social and economic rights in understanding the cause of conflict and victims' needs and, on the other hand, their marginalisation in transitional justice processes (McEvoy and McConnachie, 2013; Robins, 2017).

While some victims expected individual payments to compensate for specific material losses, in order to then be able to build homes, many others emphasised the need for money to perform Buddhist ceremonies (Williams et al., 2018: 112). In the words of one civil party: 'We cannot perform religious ceremonies without money. When we demand something like this [individual financial reparations], it seems like it is all about money, money, money. It does not mean that I want that money to be rich. I just want to pay respect to the deceased, for them to feel at ease'. ${ }^{15}$ These ceremonies are crucial for people to deal with the past as they are needed to support the spirits of the dead in their quest for re-birth (Arensen, 2017). As such, the spiritual system interacts strongly with a perception of limited resources in the legal and economic systems, undermining resilience.

Besides direct financial payments, some victims suggest that they would like all victims to be given rice to help them survive or free health care, arguing that their health 'was destroyed by the Khmer Rouge regime due to the lack of food and medical care'. ${ }^{16}$ Both demands illustrate how a lack of resources for resilience in the economic system shapes what people need from transitional justice - and their frustrations relating to participation.

14 These reparations are 'collective and moral', meaning that they are to be symbolic and 'a) acknowledge the harm suffered by Civil Parties as a result of the commission of the crimes for which an Accused is convicted and b) provide benefits to the Civil Parties which address this harm. These benefits shall not take the form of monetary payments to Civil Parties' (ECCC, 2015: 26). The interview, with a civil party at the ECCC, was conducted in Phnom Penh in 2018.

16 The interview, with a civil party of case ooz at the ECCC, was conducted in Kampong Cham province in $2018(\mathrm{JB})$. 


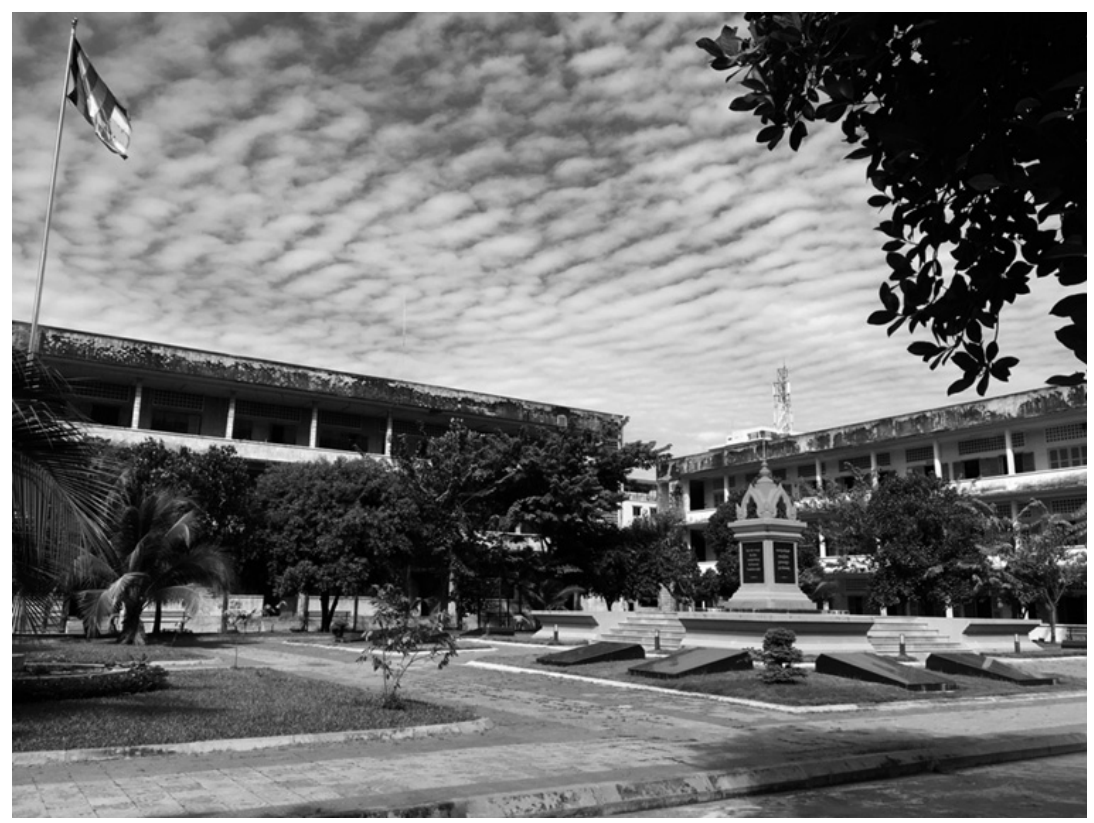

FIGURE 7.1 Memorial to those killed after being incarcerated at the S-21 security centre, one of the ECCC reparation projects. Photo by the author.

Turning now to the actual collective and moral reparations that are designed and implemented by NGOs (ideally in consultation with the civil parties), multiple reparations projects exist. These include testimonial therapy programmes, a memorial (see Figure 7.1), a national remembrance day, the listing of names in ECCC judgments, a play about moral courage and a traditional apsara dance performance about forced marriage (see Hughes, 2016: 158-160; Jasini, 2016: 41-46). The reparations are similar to many other projects implemented to deal with the past outside the judicial setting, possibly explaining why the vast majority of victims, even those who had taken part in the programmes, did not know that they were actually even participating in reparative projects (Sperfeldt et al., 2016: 57; Williams et al., 2018: 116). While there is little rigorous evaluation of the impact of the reparations, interviews and participant observation of the events connected to these reparations projects would suggest that they are indeed meaningful for the participants. In particular, many interviewees mentioned the Transcultural Psychological Organization (TPO) as having provided significant relief and contributed to resilience by improving their mental health and allowing people to better deal with their past and participate in community life today. 
One example of a reparations project that is particularly interesting as a broad collaboration of four organisations ${ }^{17}$ is the dance theatrical performance Pka Sla Krom Angkar (see Grey et al., 2019; Shapiro-Phim, 2020). It was choreographed by Sophiline Cheam Shapiro and originally initiated by Theresa de Langis, whose interview-based research informs the performance (de Langis et al., 2014). The dance performance (see Figure 7.2) deals with the crime of forced marriage and tells the story of one particular couple, Kesar and Mony, although this is interlaced with the stories of other couples forced to marry. ${ }^{18}$ Most scenes are set during Democratic Kampuchea but commented upon by Kesar and Mony from today's perspective. It is a particularly important project given that many victims were not even aware that state-led forced marriage constituted a crime in a culture where arranged marriages are common. As such, the dance performance, as well as the trial in Case 002/ $\mathrm{O} 2$ at the ECC, rendered visible the trauma that forced marriages had caused,

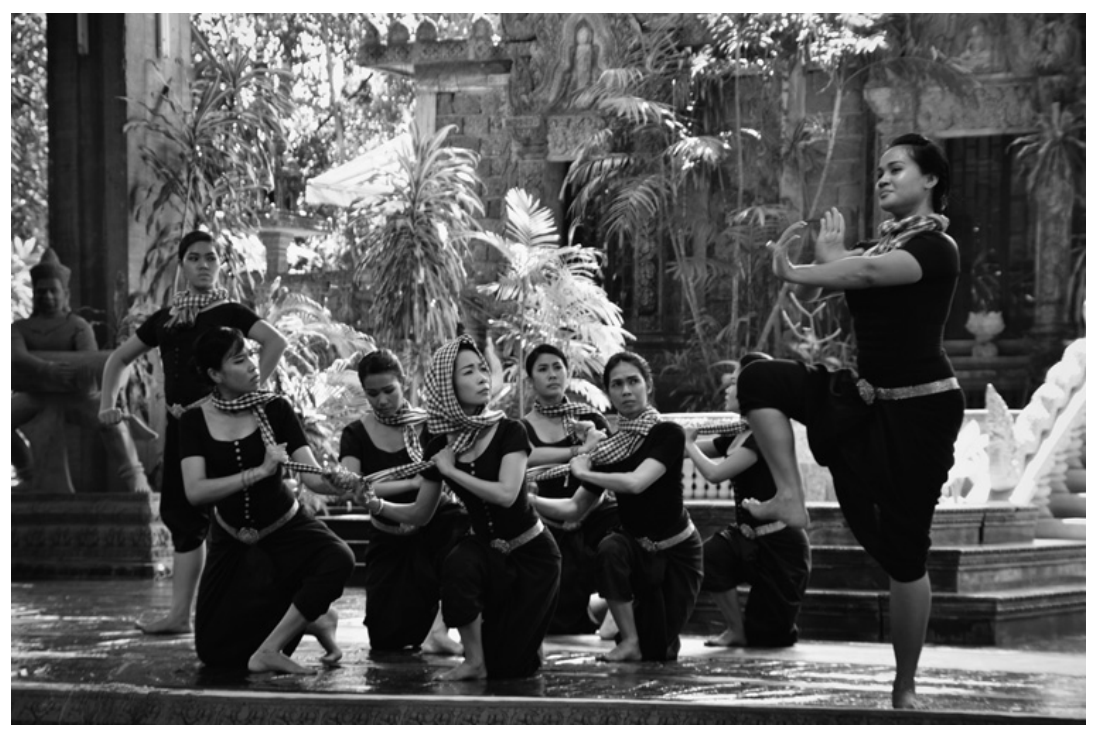

Figure 7.2 Pka Sla Krom Angkar dance performance. Photo by the ECCC, available under a creative commons license. ${ }^{19}$

${ }_{17}$ The four collaborating organisations are the TPO, Kdei Karuna and Bophana Audiovisual Resource Center, all of which have worked extensively on dealing with the Khmer Rouge past, and Khmer Arts, a cultural organisation.

18 I was able to observe both the premiere live in January 2017 and a subsequent recording and panel discussion.

19 See www.flickr.com/photos/krtribunal/32489803780/. 
allowing the suffering to be expressed and articulated. The success of this reparations project from the social-ecological resilience perspective of this chapter is that it ties into other systems, connecting cultural dealings with the past to social systems that can be repaired after forced marriage.

\section{THE LIMITATIONS OF TRANSITIONAL JUSTICE FOR ADAPTIVE PEACEBUILDING IN CAMBODIA}

While some of the limitations discussed in the previous section are due to the way that transitional justice was designed, most are rooted in its relationships with other systems, including how these systems affected its design in the first place. Specifically, in Cambodia, transitional justice interacts with dysfunctional and resource-depleted political, economic and legal systems, which, in turn, constrain its full transformative potential. In this final section, I turn to one of the key interests of this volume, namely the relationship between transitional justice and adaptive peacebuilding - and how the former might aid the latter.

Adaptive peacebuilding centres around three elements of complexity theory, namely adapting to uncertainty, focusing on means rather than ends and emphasising change as opposed to working against it. These elements are significant in evaluating how transitional justice can support adaptive peacebuilding in Cambodia. On the issue of adapting to uncertainty, adaptive peacebuilding (de Coning, 2018) sees conflict not as juxtaposed to peacebuilding but as an inherent part of it, and it emphasises that the avoidance of violence and good management of conflict are key. In this sense, it ties in well with the concept of social-ecological resilience and how conflict can be mitigated and contained through the interactions and collaborations of various systems. While Cambodia's transitional justice process is implemented in a context of relative uncertainty, it has avoided stoking larger conflicts. However, it has fuelled conflict at the local level about who can participate in the ECCC's proceedings, linked to the aforementioned patronage-based networks. In this sense, it has not optimally adapted to the individual-level uncertainties that exist within the illiberal political system. There is also some degree of conflict around disappointed hopes, in particular related to the absence of individual financial reparations. At the same time, transitional justice has made positive contributions to Cambodian society, for example, by reinforcing the aforementioned government narrative of universal victimhood that allows for easier reconciliation through emphasis on the victimhood of former low-level Khmer Rouge cadres and enabling adaptation to deepseated uncertainty about how to handle local relations (Williams, 2018a). 
Regarding the second element of adaptive peacebuilding - accentuating means rather than ends - transitional justice also helps by shifting the focus from a defined liberal end point to the actual implementation of the justice project. In Cambodia, it has been particularly necessary in the context of implementing transitional justice to pragmatically compromise on some higher-order goals in order to accommodate the regime's political interests. For example, the acceptance of patronage networks in staffing the ECCC or in structuring victim participation plays to key political interests while still forwarding a transformative agenda.

It is particularly in relation to the third element of adaptive peacebuilding, the focus on change, where we can see an undermining of transitional justice's broader impact on adaptive peacebuilding. Transitional justice is inherently embedded in the idea of transition and change. In Cambodia, however, any transformative potential is severely limited through transitional justice interactions with other systems, such as the political system of oppression and a lack of democracy in which the government forwards its own agenda, as well as economic systems of corruption and patronage. Furthermore, with international engagement in the country focused so heavily on the horrific past, transitional justice and the changes that have occurred since Democratic Kampuchea, this contributes to legitimising today's government (as a positive contrast to the past). Here, the necessity for change becomes less important, and the past masks many of the current regime's illiberal practices and today's conflicts, particularly around the violation of land rights and human rights, or the increasing constraints on the political opposition.

According to Ungar, '[w] hen one component fails, a justice system can still maintain its resilience and function properly despite an unanticipated (or anticipated) stressor' (Chapter 1). This 'reliability' of the system also works in the opposite direction. In short, transitional justice cannot positively influence other systems when it remains constrained by corruption, nepotism, political illiberalism and hegemony.

\section{CONCLUSION}

In this chapter, I have argued that, in Cambodia, transitional justice's contribution to social-ecological resilience and adaptive peacebuilding is limited. While resources for resilience have been successfully carved out in various private systems (including social systems of the family, as well as spiritual systems), in several more public systems - notably the political, economic and legal systems - there are few resources provided for resilience. Transitional justice would have the potential to contribute to resilience (and does so for 
a limited number of people), but its design and implementation are strongly embedded in these other systems - and at times even reinforce them.

In this context, the government largely fails to provide resources to deal with stressors in other systems; and indeed, for parts of the population it could itself be regarded as an additional stressor. As such, politics is very much at the centre of understanding the prospects for resilience (Joseph, 2018). Political gain can be found in not engaging in adaptive peacebuilding as the government derives greater benefits from maintaining systems of corruption and autocratic power, meaning that national actors in Cambodia have used transitional justice strategically to undermine peacebuilding.

\section{REFERENCES}

Arensen, L. J. (2017). The dead in the land: Encounters with bodies, bones and ghost in Northwestern Cambodia. The Journal of Asian Studies, 76(1), 69-86.

Bennett, C. (2018). Karma after Democratic Kampuchea: Justice outside the Khmer Rouge Tribunal. Genocide Studies and Prevention: An International Journal, 12(3), 68-82.

Bernath, J. (2016). 'Complex political victims' in the aftermath of mass atrocity: Reflections on the Khmer Rouge Tribunal in Cambodia. International Journal of Transitional Justice, 10(1), 46-66.

Chandler, D. P. (1999). Brother Number One: A Political Biography of Pol Pot. Boulder, CO: Westview.

Chandler, D. P. (2000). Voices from S-21: Terror and History in Pol Pot's Secret Prison. Chiang Mai: Silkworm.

Chandler, D. P. (2008a). A History of Cambodia, $4^{\text {th }}$ ed. Boulder, CO: Westview.

Chandler, D. P. (2008b). Cambodia deals with its past: Collective memory, demonisation and induced amnesia. Totalitarian Movements and Political Religions, 9(2), 355-369.

Chhim, S. (2013). Baksbat (broken courage): A trauma-based cultural syndrome in Cambodia. Medical Anthropology, 32(2), 160-173.

Comes, T., Meesters, K. and Torjesen, S. (2019). Making sense of crises: The implications of information asymmetries for resilience and social justice in disaster-ridden communities. Sustainable and Resilient Infrastructure, 4(3), $124-136$.

de Coning, C. (2018). Adaptive peacebuilding. International Affairs, 94(2), 301-317.

DeFalco, R. (2014). Justice and starvation in Cambodia. The Khmer Rouge famine. The Cambodia Law and Policy Journal, 3, 45-84.

DeFalco, R. (2018). The uncertain relationship between international criminal law accountability and the rule of law in post-atrocity states: Lessons from Cambodia. Fordham International Law Journal, 42(1), 1-6o.

de Langis, T., Strasser, J., Thida, K. and Sopheap, T. (2014). Like Ghost Changes Body: A Study on the Impact of Forced Marriage under the Khmer Rouge Regime. Phnom Penh: Transcultural Psychosocial Organization. 
ECCC. (2015). ECCC Internal Rule, 23 (1), Revision 9. www.eccc.gov.kh/en/docu ment/legal/internal-rules (accessed 12 October 2020).

Gidley, R. (2019). Illiberal Transitional Justice and the Extraordinary Chambers in the Courts of Cambodia. Cham: Palgrave Macmillan.

Global Witness (2016). Hostile Takeover. Report, 7 July, 2016. www.globalwitness.org /en/reports/hostile-takeover/ (accessed 14 October 2020).

Grey, R., Yim, S. and Kum, S. (2019). The Khmer Rouge Tribunal's first reparation for gender-based crimes. Australian Journal of Human Rights, 25(3), 488-497.

Hennings, A. (2016). Das Konfliktpotenzial exklusiver landgrabbing-praktiken. herausforderung für den regionalen frieden. ZeFKo, 5(2), 221-248.

Hinton, A. L. (2005). Why Did They Kill? Cambodia in the Shadow of Genocide. Berkeley, CA: University of California Press.

Hinton, A. L. (2018). The Justice Facade. Trails of Transition in Cambodia. Oxford: Oxford University Press.

Hughes, R. (2015). Ordinary theatre and extraordinary law at the Khmer Rouge Tribunal. Environment and Planning D: Society and Space, 33(4), 714-731.

Hughes, R. (2016). Victims' rights, victim collectives and utopic disruption at the Extraordinary Chambers in the Courts of Cambodia. Australian Journal of Human Rights, 22(2): 143-166.

Human Rights Watch. (2019). Cambodia: Holding a media summit without media freedom. www.hrw.org/news/2019/o6/og/cambodia-holding-media-summit-withoutmedia-freedom (accessed 7 November 2020).

Jasini, R. (2016). Victim Participation and Transitional Justice in Cambodia: The Case of the Extraordinary Chambers in the Courts of Cambodia (ECCC). Utrecht, The Netherlands: Impunity Watch.

Joseph, J. (2018). Varieties of Resilience. Studies in Governmentality. Cambridge: Cambridge University Press.

Kieran, B. (1985). How Pol Pot Came to Power. A History of Communism in Kampuchea 1930-1975. London: Verso.

Kieran, N. (1996). The Pol Pot Regime, Race, Power, and Genocide in Cambodia under the Khmer Rouge. New Haven, CT: Yale University Press.

Killean, R. (2018) Victims, Atrocity, and International Criminal Justice. Lessons from Cambodia. Abingdon: Routledge.

Ledgerwood, J. (2012). Buddhist ritual and the reordering of social relations in Cambodia. South East Asia Research, 20(2), 191-205.

Manning, P. (2017). Transitional Justice and Memory in Cambodia. Beyond the Extraordinary Chambers. Abingdon: Routledge.

McEvoy, K. and McConnachie, K. (2013). Victims and transitional justice: Voice, agency and blame. Social and Legal Studies, 22(4), 489-513.

National Bank of Cambodia. (2020). Macroeconomic and banking sector developments in 2019 and outlook for 2020. www.nbc.org.kh/download_files/other_reports/english/ Macroeconomic_and_Banking_Sector.pdf (accessed 14 October 2020).

Olsen, A. and Vorn, V. (2020). COVID-19: Impact on Cambodian Migrant Workers. Bangkok: International Labour Organization. https://abordoc.ilo.org/discovery/fulldis play/alma995091093002676/41ILO_INST:41ILO_V2 (accessed 4 November 2020).

Orentlicher, D. (2020) 'Worth the effort'? Assessing the Khmer Rouge Tribunal. Journal of International Criminal Justice, 18(3), 615-640. 
Parsons, L., Lawreniuk, L. and Pilgrim, J. (2014). Wheels within wheels: Poverty, power and patronage in the Cambodian migration system. Journal of Development Studies, $50(10), 1362-1379$.

Po, S. and Heng, K. (2019). Assessing the impacts of Chinese investments in Cambodia: The case of Preah Sihanoukville Province. A working paper on China-Cambodia relations. Issues and Insights Working Papers, 19(4), 1-19.

Robins, S. (2011). Towards victim-centred transitional justice: Understanding the needs of families of the disappeared in postconflict Nepal. International Journal of Transitional Justice, 5(1), 75-98.

Robins, S. (2017). Failing victims? The limits of transitional justice in addressing the needs of victims of violations. Human Rights and International Legal Discourse, 11 (1), 41-58.

Ryan, H. and McGrew, L. (2016). Performance and perception: The impact of the extraordinary chambers in the courts of Cambodia. New York: Open Society Justice Initiative (OSJI). www.opensocietyfoundations.org/reports/performance-andperception-impact-extraordinary-chambers-court-cambodia (accessed 12 October 2020).

Shaprio-Phim, T. (2020). Embodying the pain and cruelty of others. International Journal of Transitional Justice, 14(1), 209-219.

Sonis, J., Gibson, J. L., de Jong, J. T. V. M., Field, N. P., Hean, S. and Komproe, I. (2009). Probable posttraumatic stress disorder and disability in Cambodia. Associations with perceive justice, desire for revenge, and attitudes toward the Khmer Rouge Trails. Journal of the American Medical Association, 302(5), 527-536.

Soy, K. and Hing, V. (2019). Upholding the right to lawyer: Lessons learned from the extraordinary chambers in the courts of Cambodia. Swisspeace Working Paper 5/2019 (Cambodia Series). Bern: Swisspeace.

Sperfeldt, C. (2012a). Cambodian civil society and the Khmer Rouge Tribunal. International Journal of Transitional Justice, 6(1), 149-160.

Sperfeldt, C. (2012b). Collective reparations at the extraordinary chambers in courts of Cambodia. International Criminal Law Review, 12(3), 457-489.

Sperfeldt, C. (2020). Reparations at the extraordinary chambers in the courts of Cambodia. In C. Ferstman and M. Goetz (eds.), Reparations for Victims of Genocide, War Crimes and Crimes Against Humanity: Systems in Place and Systems in the Making. Leiden: Brill, pp. 479-504.

Sperfeldt, C., Hyde, M. and Baltharzard, M. (2016). Voices for reconciliation: Assessing media outreach and survivor engagement for case ooz at the Khmer Rouge Trials. East West Center and WSD Handa Center for Human Rights and International Justice. www.eastwestcenter.org/publications/voices-reconciliation-assessing-mediaoutreach-and-survivor-engagement-case-002-the (accessed 12 October 2020).

Springer, S. (2011). Articulated neoliberalism: The specificity of patronage, kleptocracy, and violence in Cambodia's neoliberalization. Environment and Planning A: Economy and Space, 43(11), 2554-2570.

Strasser, J., Thida, K., Studzinsky, S. and Taking, S. (2015). A Study about Victims' Participation at the Extraordinary Chambers in the Courts of Cambodia and GenderBased Violence under the Khmer Rouge Regime. Phnom Penh: Transcultural Psychosocial Organization Cambodia (TPO).

Tabeau, E. and Kheam, T. (2009). Demographic Expert Report: The Khmer Rouge Victims in Cambodia, April 1975-January 1979. A Critical Assessment of Major 
Estimates. Extraordinary Chamber in the Courts of Cambodia (ECCC), 30 September 2009. www.eccc.gov.kh/sites/default/files/documents/courtdoc/D14O_ 1_1_Public_Redacted_EN.PDF (accessed 14 October 2020).

Transparency International. (2019). Country data - Cambodia. www.transparency.org /en/countries/cambodia (accessed 15 October 2020).

Un, K. (2019). Cambodia: Return to Authoritarianism. Cambridge: Cambridge University Press.

Ungar, M. (2018). Systemic resilience: Principles and processes for a science of change in contexts of adversity. Ecology and Society, 23(4): 34 .

United Nations Development Programme. (2020). About Cambodia. www.kh.undp.org /content/cambodia/en/home/countryinfo.html (accessed 14 October 2020).

Williams, T., Bernath, J., Tann, B. and Kum, S. (2018). Justice and Reconciliation for the Victims of the Khmer Rouge? Victim Participation in Cambodia's Transitional Justice Process. Research report. Marburg: Centre for Conflict Studies; Phnom Penh: Centre for Study of Humanitarian Law; Bern: Swisspeace.

Williams, T. (2018a). Perpetrator-victims. How universal victimhood in Cambodia impacts dealing with the past and transitional justice measures. In N. Adler (ed.), Understanding the Age of Transitional Justice: Narratives in Historical Perspective. New Brunswick, NJ: Rutgers University Press, pp. 194-212.

Williams, T. (2018b). Agency, responsibility and culpability: The complexity of roles and self-representations of perpetrators. Journal of Perpetrator Research, 2(1), 39-64.

Williams, T. (2019). NGO interventions in the post-conflict memoryscape: The effect of competing 'mnemonic role attributions' on reconciliation in Cambodia. Journal of Intervention and Statebuilding, 13(2), 158-179.

World Bank. (2020). World Bank data on agriculture and rural development. https:// data.worldbank.org/topic/agriculture-and-rural-development?locations $=\mathrm{KH}$ (accessed 14 October 2020). 